\title{
Literasi Digital Untuk Penjualan Bagi Komunitas UMKM Kuliner Pasar Lama Tangerang
}

\author{
Fahlepi Roma Doni' ${ }^{1}$, Budi Sudrajat ${ }^{2}$, Hasta Herlan Asymar ${ }^{3}$ \\ 1,2,3 Teknologi Komputer/Universitas Bina Sarana Informatika \\ *e-mail: fahlepi.fro@bsi.ac.id ${ }^{1}$, budi.bst@bsi.ac.id ${ }^{2}$,hasta.hsh@bsi.ac.id $^{3}$
}

\begin{abstract}
The Old Market of Tangerang City is famous as a culinary tourism area which is quite crowded, before the Covid-19 Pandemic hundreds of food (culinary) trades were seen lined up along the road in the Old Market of Tangerang City. UMKM trade transactions along this culinary tourism area reach billions of rupiah. However, since the corona outbreak (Covid-19) this area is no longer busy and lively. Along the road looks deserted from UMKM traders. Currently only modern retail stores, opticians, flower shops, as well as clothing and grocery stores remain open. However, the buyers were not so much. For this, there is a need for understanding and knowledge for UMKM actors regarding how to use internet media to support their activities. The form of activity that can be provided for MSME actors is to provide knowledge and understanding to them on how to utilize technology and internet media to be used in promoting their business activities, especially for members of the UMKM Community, the Old Market Culinary Center, Tangerang City. The material provided was in the form of seminar activities to members of the MSME Community at the Old Market Culinary Center in Tangerang City with the theme "Digital Literacy for UMKM Amid the Covid-19 Pandemic". The implementation of this activity is carried out directly at the location of UMKM. By holding this activity, it is hoped that it can provide increased knowledge and skills for participants, provide change by increasing turnover and profits for UMKM actors and can increase the number of entrepreneurs who want to work in the UMKM sector..
\end{abstract}

Keywords:Covid-19, Digital Literacy, UMKM

\begin{abstract}
Abstrak
Pasar Lama Kota Tangerang terkenal sebagai kawasan wisata kuliner yang cukup ramai, sebelum ada Pandemi Covid-19 ratusan pedagangan makanan (kuliner) terlihat berjejer di sepanjang jalan yang ada di Pasar Lama Kota Tangerang. Transaksi perdagangan UMKM sepanjang kawasan wisata kuliner ini mencapai miliaran rupiah. Namun, sejak terjadi wabah corona (Covid-19) kawasan ini tidak lagi sibuk dan meriah. Sepanjang jalan terlihat sepi dari pedagang UMKM. Saat ini hanya toko-toko ritel modern, optic, toko bunga, serta pakaian dan toko bahan pangan yang tetap buka. Namun, pembelinya pun tidak begitu banyak. Untuk ini perlunya pemahaman dan pengetahuan bagi pelaku UMKM terkait bagaimana memanfaatkan media internet untuk menunjang kegiatan mereka. Bentuk kegiatan yang dapat diberikan bagi para pelaku UMKM yaitu memberikan pengetahuan dan pemahaman kepada mereka bagaimana caranya untuk memanfaatkan teknologi dan media internet untuk bisa digunakan dalam mempromosikan kegiatan usahanya terutama untuk anggota Komunitas UMKM Pusat Kuliner Pasar Lama Kota Tangerang. Materi yang diberikan berupa kegiatan seminar kepada anggota Komunitas UMKM Pusat Kuliner Pasar Lama Kota Tangerang dengan tema "Literasi Digital Bagi Pelaku UMKM Di Tengah Pandemi Covid-19”. Pelaksanaan kegiatan ini dilakukan secara langsung di lokasi UMKM. Dengan diadakannya kegiatan ini diharapkan dapat memberikan pengetahuan dan keterampilan yang meningkat bagi peserta, memberikan perubahan dengan meningkatnya omzet dan keuntungan bagi pelaku UMKM dan dapat menambah jumlah wirausaha yang mau bergerak di bidang UMKM.
\end{abstract}

Kata kunci: Covid-19, Literasi Digital, UMKM 


\section{PENDAHULUAN}

Pada masa Pandemi Covid-19 seperti saat ini penggunaan internet sangat penting sekali di dalam semua kegiatan masyarakat. Salah satu bagian masyarakat yang diharapkan dapat bertransformasi ke dalam dunia digitalisasi adalah para pelaku Usaha Mikro Kecil Menengah (UMKM). Usaha mikro yang kecil atau UMKM yaitu identitas suatu usaha dimana memiliki peran strategi untuk upaya peningkatan perekonomian indonesia. UMKM sekarang mempunyai peran sebagai tulang punggung yang ada pada bangsa Indonesia (Thamrin Tahir,et al, 2021). Digitalisasi meminimalkan kontak secara langsung yang berarti juga dapat meminimalkan risiko penyebaran Virus Covid-19. Karena itu salah satu tantangan berat yang harus dilakukan adalah meningkatkan literasi manfaat UMKM masuk ke dalam sistem digital dan inkubasi untuk mengeksplorasi kesiapan UMKM (Wijoyo, Hadion, et al, 2020).

Pandemi Covid-19 telah membuat menurunya daya beli masyarakat. Dikarenakan publik telah mengurangi interaksi diluar ruangan untuk menekan persebaran pandemi. Dengan demikian, banyak konsumen yang kemudian menjaga jarak dan mengalihkan pembelian secara digital. Dampaknya banyak UMKM yang harus menutup usahanya karena menurunya pembelian dan masih tergantung pada penjualan secara luar jaringan (offline). Sehingga beberapa sektor UMKM yang belum beradaptasi secara digital pada akhirnya sangat terdampak hingga menutup gerainya (Arianto 2020).

Pengguna internet di Indonesia setiap tahun berkembang sangat pesat. Berdasarkan data yang di dapat dari https://databoks.katadata.co.id/ penetrasi internet di Indonesia pada akhir Maret 2021 sebesar 76,8\% dari total populasi (Kusnandar 2021). Berdasarkan http://perpustakaan.kemendagri.go.id/? $\mathrm{p}=5018$, pemerintah pun ingin memastikan agar pelaku usaha dapat mengoptimalkan beragam manfaat yang dihadirkan melalui penggunaan internet. Salah satunya pada ekonomi digital. Seperti diketahui, potensi ekonomi digital Indonesia diproyeksi mencapai sekitar 124 miliar dollar Amerika Serikat (AS) pada 2025. Pada web seminar (webinar) Literasi Digital, Menteri Komunikasi dan Informatika (Menkominfo) Johnny G Plate mengatakan, pemerintah tengah melakukan akselerasi pengembangan sumber daya manusia (SDM) di bidang digital. Dengan perkembangan terhadap penggunaan internet, membuat teknologi berkembang semakin pesat dan banyak terjadi transformasi digital di segala bidang kehidupan masyarakat (Kompas.com 2021).

Penggunaan media internet sebagai alat jaringan sosial tidak hanya dalam membagikan kegiatan si pengguna namun dapat meningkatkan penggunaan bisnis secara online. Media sosial juga dapat mempunyai tujuh fungsi potensial dalam bisnis yaitu mengidentifikasi pelanggannya, mengadakan komunikasi timbal balik, membagikan informasi untuk dapat mengetahui obyek yang disukai pelanggan, kehadiran pelanggan, hubungan antar pelanggan berdasarkan lokasi dan pola interaksi, reputasi perusahaan di mata pelanggan dan membentuk kelompok antar pelanggan (Rizki Isnanda 2018) . Banyak aplikasi yang dapat mendukung dalam proses penjualan online, terutama aplikasi OLX dan pemasaran online melalui portal $e$ commers (Desyanti, Febrina Sari, Wetri Febrina 2021)

Pengenalan sistem pemasaran digital ini diharapkan para pelaku UMKM bisa lebih mengoptimalkan dan meningkatkan pengetahuan mengenai sistem pemasaran digital atau sistem pemasaran online, sebab melalui sistem pemasaran digital atau sistem pemasaran online produk-produk dari UMKM akan dapat lebih dikenal oleh masyarakat, pemesanan bisa dilakukan secara online, sehingga dapat memudahkan pembeli dan pelaku UMKM dalam bertransaksi jual beli ditengah pandemi covid-19 saat ini. Peserta dapat merancang bisnis online baru mereka, proses dan tahapan pembuatan promosi melalui aplikasi sosial media sehingga lebih optimal dibandingkan bisnis mereka sebelumnya (Satria et al. 2021) 
Pasar Lama Kota Tangerang terkenal sebagai kawasan wisata kuliner yang cukup ramai, sebelum ada Pandemi Covid-19 ratusan pedagangan makanan (kuliner) terlihat berjejer di sepanjang jalan yang ada di Pasar Lama Kota Tangerang. Transaksi perdagangan UMKM sepanjang kawasan wisata kuliner ini mencapai miliaran rupiah. Namun, sejak terjadi wabah corona (Covid-19) kawasan ini tidak lagi sibuk dan meriah. Sepanjang jalan terlihat sepi dari pedagang UMKM. Saat ini hanya toko-toko ritel modern, optic, toko bunga, serta pakaian dan toko bahan pangan yang tetap buka. Namun, pembelinya pun tidak begitu banyak.

Kondisi saat ini menuntut para pelaku UMKM harus dapat bertransformasi bentuk usahanya. Sebelumnya banyak pelaku usaha yang masih menggunakan cara konvensional dalam memasarkan produk-produknya, di masa seperti ini mereka dituntut bisa menggunakan teknologi seperti media internet, penggunaan smartphone, pemasaran produk melalui media sosial, marketplace, dan lain-lain untuk tetap bisa menjalankan usahanya di tengah kondisi pandemi sekarang ini. Untuk ini perlunya pemahaman dan pengetahuan bagi pelaku UMKM terkait bagaimana memanfaatkan media internet untuk menunjang kegiatan mereka (Soetjipto 2020)

\section{METODE}

Metode Pelaksanaan kegiatan pengabdian kepada masyarakat langkah awal adalah survey ke lokasi instansi yang akan dijadikan tempat pelaksanan pengabdian masyarakat dan melakukan kesepakan untuk pelaksanaannya. Setelah terjadi kesepakatan antara kedua belah pihak langkah selanjutnya yaitu pembuatan materi yang akan disampaikan pada saat pelaksanaan pengabdian nya. Dalam pelaksanaan masing-masing anggota berbagi tugas dalam kegiatan tersebut. Setelah pelaksanaan kegiatan semua panitia melakukan evaluasi kegiatan dan menyusun laporan pelaksanaan. Berikut ini alur dari metode pelaksanaan pengabdian masyarakat :

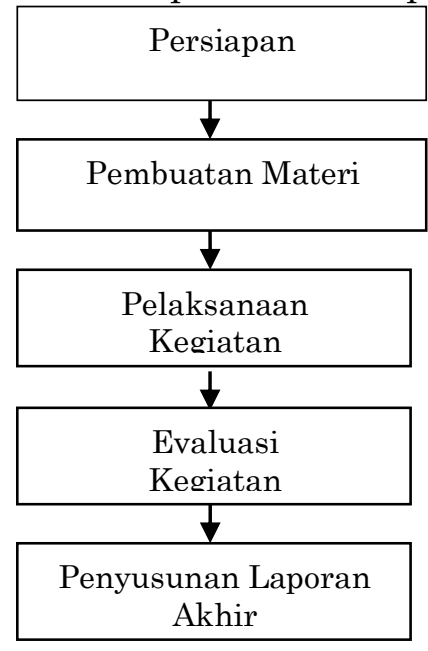

Gambar 1. Metode Pelaksanaan Pengabdian Masyarakat

Materi yang diberikan berupa kegiatan pelatihan kepada anggota Komunitas UMKM Pusat Kuliner Pasar Lama Kota Tangerang dengan tema "Literasi Digital Bagi Pelaku UMKM Di Tengah Pandemi Covid-19". Pelaksanaan kegiatan ini dilakukan secara langsung di lokasi UMKM dengan dilakukan protokol kesehatan yang ketat. Target Peserta Pengabdian Masyarakat ini adalah 20 orang peserta.

Susunan panitia kegiatan pengabdian masyarakat sebagai berikut:

Penanggung Jawab : Dr. Mochamad Wahyudi, MM, M.Kom, M.Pd

Ketua pelaksana : Fahlepi Roma Doni, M.Kom, Mengatur tugas dari 
Tutor

Anggota

Mahasiswa masing-masing anggota dan bertanggung jawab atas pelaksanaan Pengabdian Masyarakat

: Budi Sudrajat, M.Kom, Membuat dan menyampaikan materi kepada peserta pengabdian masyarakat

: Hasta Herlan Asymar, ST, MM, Menyiapkan keperluan teknis dalam pelaksanaan pengabdian masyarakat dan membuat pressrelease dan Dokumentasi dan penyusunan laporan Pengabdian Masyarakat

: Wahyu Nur Pradana, Muhammad Zaki Ardi dan Muhamad Wahyu Kholik, Membantu menjadi pendamping tutor dalam penyampaian materi.

\section{HASIL DAN PEMBAHASAN}

Tema pelaksanaan kegiatan Pengabdian Masyarakat ini yaitu "Teknologi Literasi Digital untuk Penjualan bagi Komunitas UMKM Kuliner Pasar Lama Tangerang" sudah selesai dilaksanakan. Berikut ini hasil kuisioner dari 20 peserta dalam Pengabdian Masyarakat ini :

\begin{tabular}{|c|c|c|c|c|c|c|c|c|c|c|c|}
\hline \multirow[b]{2}{*}{ No. } & \multicolumn{3}{|c|}{ Data Responden } & \multicolumn{2}{|c|}{$\mathbf{P 1}$} & \multicolumn{2}{|c|}{ P2 } & \multicolumn{2}{|c|}{ P3 } & \multicolumn{2}{|c|}{ P4 } \\
\hline & Nama Responden & $\mathbf{L} / \mathbf{P}$ & Umur & Puas & $\begin{array}{c}\text { Tidak } \\
\text { Puas }\end{array}$ & Puas & $\begin{array}{c}\text { Tidak } \\
\text { Puas }\end{array}$ & Puas & $\begin{array}{c}\text { Tidak } \\
\text { Puas }\end{array}$ & Puas & $\begin{array}{l}\text { Tidak } \\
\text { Puas }\end{array}$ \\
\hline 1 & Sukardi Zulkarnain & $\mathbf{L}$ & $>50$ & 1 & & 1 & & 1 & & 1 & \\
\hline 2 & Cendy Nuzul R & $\mathbf{P}$ & $<30$ & 1 & & 1 & & 1 & & 1 & \\
\hline 3 & M. Fiqri Wijjaya & $\mathbf{L}$ & $<30$ & 1 & & 1 & & 1 & & 1 & \\
\hline 4 & Hendi & $\mathbf{L}$ & $>50$ & 1 & & 1 & & 1 & & 1 & \\
\hline 5 & Setias Nawati & $\mathbf{P}$ & $\begin{array}{l}36- \\
40\end{array}$ & 1 & & 1 & & 1 & & 1 & \\
\hline 6 & Wasrul & $\mathbf{L}$ & $\begin{array}{l}46- \\
50\end{array}$ & 1 & & 1 & & 1 & & 1 & \\
\hline 7 & Dian Fitri & $\mathbf{P}$ & $\begin{array}{l}36- \\
40\end{array}$ & 1 & & 1 & & 1 & & 1 & \\
\hline 8 & Nita & $\mathbf{P}$ & $<30$ & 1 & & 1 & & 1 & & 1 & \\
\hline 9 & Sukmana & $\mathbf{L}$ & $>50$ & 1 & & 1 & & 1 & & 1 & \\
\hline 10 & Agus Leo Handoko & $\mathbf{L}$ & $\begin{array}{l}36- \\
40\end{array}$ & 1 & & 1 & & 1 & & 1 & \\
\hline 11 & Priski Setiawan & $\mathbf{L}$ & $<30$ & 1 & & 1 & & 1 & & 1 & \\
\hline 12 & M. Fauqo Aulia & $\mathbf{L}$ & $<30$ & 1 & & 1 & & 1 & & 1 & \\
\hline 13 & Murha sanah & $\mathbf{P}$ & $\begin{array}{l}36- \\
40\end{array}$ & 1 & & 1 & & 1 & & 1 & \\
\hline 14 & Ivan Ashari & $\mathbf{L}$ & $\begin{array}{l}36- \\
40\end{array}$ & 1 & & 1 & & 1 & & 1 & \\
\hline 15 & Saras Farah Diba & $\mathbf{P}$ & $<30$ & 1 & & 1 & & 1 & & 1 & \\
\hline 16 & Lulu Raihan & $\mathbf{L}$ & $\begin{array}{l}31- \\
35\end{array}$ & 1 & & 1 & & 1 & & 1 & \\
\hline 17 & Gido Khairunahar & $\mathbf{P}$ & $<30$ & 1 & & 1 & & 1 & & 1 & \\
\hline 18 & Razelia & $\mathbf{P}$ & $<30$ & 1 & & 1 & & 1 & & 1 & \\
\hline 19 & Farhan & $\mathbf{L}$ & $<30$ & 1 & & 1 & & 1 & & 1 & \\
\hline 20 & Aminah & $\mathbf{P}$ & $\begin{array}{l}36- \\
40\end{array}$ & 1 & & 1 & & 1 & & 1 & \\
\hline
\end{tabular}

Keterangan :

$\mathrm{P} 1$ = Personil/anggota yang terlibat dalam kegiatan pengabdian masyarakat memberikan pelayanan sesuai dengan kebutuhan peserta 
P2 = Tutor menyampaikan materi kegiatan dengan jelas dan mudah dimengerti oleh peserta

P3 = Setiap keluhan/pertanyaan/permasalahan yang diajukan ditindaklanjuti dengan baik oleh tutor yang terlibat

P4 = Materi yang disampaikan sesuai dengan kebutuhan peserta dalam menambah wawasan, pengetahuan, keterampilan dan keahlian peserta

Dari hasil kuisioner yang diberikan kepada peserta semua menjawab puas atas pelaksanaan pengabdian masyarakat ini.

Kegiatan pengabdian masyarakat ini dilaksanakan pada tanggal 2 Oktober 2021 bertempat di UMKM Pusat Kuliner Pasar Lama Kota Tangerang, Jalan Kali Pasir Indah No. 59 Rt 001/004 Sukasari, Kec Tangerang Kota Tangerang Banten 15118. Kegiatan pengabdian masyarakat ini diawali penyampaian kata sambutan dari Ketua UMKM Pusat Kuliner Pasar Lama Tangerang dilanjutkan dengan kata sambutan dari Ketua Tim Pengabdian Masyarakat Universitas Bina Sarana Informatika. Setelah itu penyampaian materi mengenai teknologi literasi digital untuk penjualan.

Materi yang disampaikan yaitu penggunaan di akun aplikasi media penjualan online seperti media sosial ataupun di marketplace yang dapat digunakan untuk mempromosikan kegiatan usahanya, melalui fiitur-fitur yang ada di aplikasi tersebut untuk anggota Komunitas UMKM Pusat Kuliner Pasar Lama Kota Tangerang, dimana saat ini tidak mudah melakukan kegiatan usaha secara langsung dikarenakan adanya pembatasan jam operasional terhadap pelaku usaha.

Tabel 1. Rekapitulasi Keaktifan dan Hasil Luaran Pengabdian Masyarakat

\begin{tabular}{ccc}
\hline & \multicolumn{2}{c}{ Persiapan } \\
\hline Tahapan & \multicolumn{1}{c}{ Tujuan } & \multicolumn{1}{c}{ Hasil } \\
\hline Pembentukan Panitia Kegiatan & $\begin{array}{l}\text { Pembuatan struktur dan } \\
\text { pembagian tugas }\end{array}$ & $\begin{array}{l}\text { Stuktur terdiri dari tim } \\
\text { dosen UBSI }\end{array}$ \\
& Mengelola Kegiatan dan & Daftar hadir peserta dan \\
Administrasi Kegiatan & bukti hasil kegiatan & $\begin{array}{l}\text { tim dosen serta berita } \\
\text { Pembuatan Modul dan Banner }\end{array}$ \\
& Membuat modul dan banner & Materi berupa Literasi \\
& serta bahan presentasi & Digital bagi Komunitas \\
& & UMKM kuliner Kota \\
& & Tangerang. \\
\hline
\end{tabular}




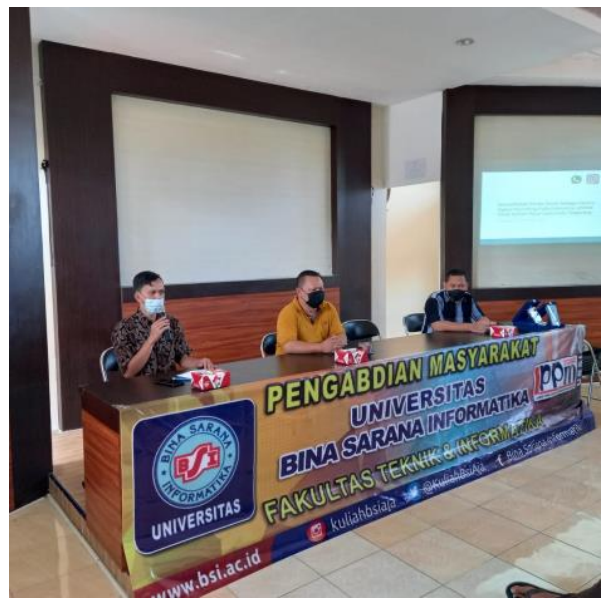

\section{Gambar 2. Sambutan Ketua Pelaksana Bapak Fahlepi Roma Doni,M.Kom}

Materi pelatihan literasi digital untuk penjualan bagi pelaku UMKM ini disampaikan oleh tim dosen dari Universitas Bina Sarana Informatika didepan para peserta dalam hal ini pelaku UMKM Kuliner Kota Tangerang. Dimulai dengan penyampaian materi dan diakhiri dengan diskusi dan tanya jawab.

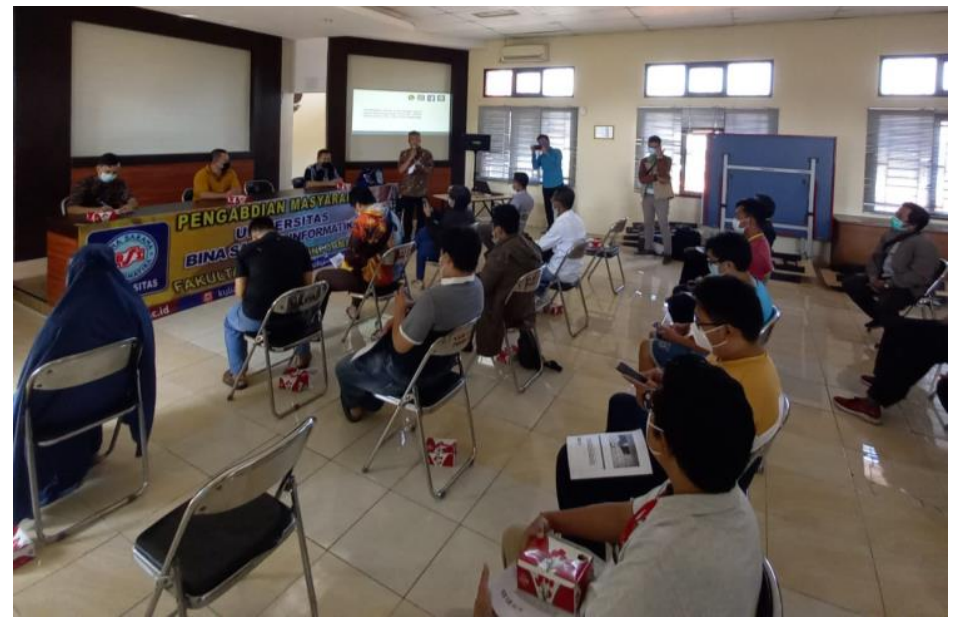

Gambar 3. Penyampaian Materi oleh Tim Tutor

Dari penyampaian materi yang disampaikan oleh tim tutor diharapkan menjadi solusi untuk meningkatkan penjualan dimasa pandemi covid-19 khususnya bagi pelaku UMKM Kuliner Pasar lama Kota Tangerang dan juga menumbuhkan kreativitas dalam penggunaan internet (media online).

\section{KESIMPULAN}

Kegiatan pengabdian masyarakat yang telah dilaksanakan telah berhasil dengan baik, para pelaku UMKM Pusat Kuliner Pasar Lama Kota Tangerang sebagai sasaran dalam kegiatan pengabdian masyarakat ini sangat antusias dalam mengikuti setiap pemaparan materi dari tim tutor. Ketika kegiatan tatap muka secara langsung saat ini dibatasi, pengurangan kegiatan transaksi secara langsung para pelaku UMKM bisa merambah ke dunia digital agar bisa melakukan penjualan secara online tanpa harus bertemu atau tatap muka 


\section{DAFTAR PUSTAKA}

Arianto, B., 2020. Pengembangan UMKM Digital di Masa Pandemi Covid-19,

Desyanti D, Febrina Sari, Wetri Febrina, M.A., 2021. Peningkatan Minat dan Skill Kewirausahaan Mayarakat di Kelurahan Bukit Batrem , Kota Dumai. Masyarakat Berdaya dan Inovasi, 2(2), pp.150-158.

Kompas.com, 2021. pemerintah pun ingin memastikan agar pelaku usaha dapat mengoptimalkan beragam manfaat yang dihadirkan melalui penggunaan internet. Kompas.com.

Kusnandar, V.B., 2021. penetrasi internet di Indonesia pada akhir Maret 2021 sebesar $76,8 \%$ dari total populasi.

Rizki Isnanda, E., 2018. Analisis Penggunaan Media Sosial untuk Mendukung Pemasaran Produk UMKM (Studi Kasus Kabupaten Subang, Jawa Barat). Jurnal Pengabdian Kepada Masyarakat, pp.1-4.

Satria, D., Arif, M. \& Hafrida, E., 2021. Pelatihan Kewirausahaan Bina Bisnis Online Pemasaran Produk Makanan Dan Reseller Untuk Kelompok Perwiridan Al Mubarok. ABDINE: Jurnal Pengabdian Masyarakat, 1(1), pp.20-25.

Soetjipto, N., 2020. Ketahanan UMKM Jawa Timur Melintasi Pandemi COVID-19,

Thamrin Tahir, M.I.S., Ahmad, Nurjannah, S.R. \& Hasan, M., 2021. Perilaku berwirausaha umkm sektor kuliner dalam perspektif literasi digital. In Digital Generation For Digital Nation. pp. 144-154.

Wijoyo, Hadion, Hamzah Vensuri, Musnaini; Widiyanti, Denok Sunarsih, Haudi, Dodi Prasada, Lilly Setyawati, Kristianti, Asep Muhammad Lutfi, I.R.A., 2020. Digitalisasi UMKM, Insan Cendekia Mandiri. 